\title{
EDITORIAL: KOERS VOLUME 80, NO 4, 2016
}

\begin{abstract}
Author:
A Combrink $^{1}$

\section{Affiliation:}

${ }^{1}$ Research associate, Department Languages and Literature, North West University.
\end{abstract}

\section{Correspondence to:}

A Combrink

Email:

anette.combrink@nwu.ac.za

Postal address:

PO Box 19124, Noordbrug 2522

\section{Dates:}

15 Dec. 2015

\section{How to cite this article:}

Combrink, A., 2015.

"Editorial: KOERS

Volume 80, No 4, 2015".

KOERS - Bulletin for

Christian Scholarship, 80(4). Available at: http:// dx.doi.org/10.19108/

koers.80.4.2242.

\section{Copyright:}

(C) 2015. The Author(s). Published under the

Creative Commons

Atribution License.
Gedurende 2015 het die hoër onderwyssektor in Suid Afrika vir die eerste keer na die volledige demokratisering van die samelewing in 1994 gebuk gegaan onder ongekende protesaksies en geweld. Een van die kenmerke van hierdie aksies was die nasionale omvang daarvan, alhoewel dit ook die geleentheid gebied het om sekere probleme op plaaslike vlakke ook uit te lig. Binne die konteks van die Noordwes-Universiteit is hierdie nasionale protes veral beliggaam deur ' $n$ studente-groepering wat bekend staan as Reform PUK. Hierdie groep het'n Manifesto die lig laat sien waarin 'n aantal spesifieke brandpunte gelys word. Alhoewel hierdie sake veral fokus op die Potchefstroom-kampus het onrus by die Vaaldriehoek- en die Mafikengkampus daarop gedui dat van hierdie sake ook binne die breër instelling ongemak onder studente meebring. Die nasionale omvang van die protesaksie beklemtoon die geldigheid van hierdie interpretasie. Twee van die sake wat in Reform PUK se Manifesto onder die loep kom, is die dekolonialisering van die kampus, met spesifieke verwysing na die Potchefstroomkampus, asook 'n verwysing na 'n "Eurosentriese kurrikulum".

In die lig hiervan rig die redaksie van Koers 'n uitnodiging aan akademici om hierdie resente ontwikkelinge vanuit hulle betrokke vakgebiede binne' $n$ akademiese konteks te bestudeer. Ons sal graag artikels vanuit verskillende vakgebiede publiseer wat akademiese kontekstualisering en insig bied op hierdie ongekende optrede binne'n demokratiese samelewing. Artikels wat spesifieke aandag gee aan veral die geopperde probleme rondom dekolonialisering, asook 'n Eurosentriese kurrikulum sal oorweeg word.

During 2015, for the first time after the complete democratization of society in 1994, the higher education sector in South Africa witnessed unparalleled protest actions and violence. One of the key characteristics of these actions was their national scope, although it also provided the opportunity to raise certain issues pertaining to a more local context. In the context of the North-West University, this national protest became embodies in a student organisation known as Reform PUK. This group published a Manifesto in which a number of specific burning issues were raised. Although these issues have direct bearing on the Potchefstroom Campus, unrest on the Vaal Triangle and Mafikeng campuses indicated that these issues are also creating unease for students in the broader institution. The national scope of the unrest underscores the validity of this interpretation. Two of the issues raised by Reform PUK in their Manifesto are decolonizing the campus, with particular allusion to the Potchefstroom Campus, as well as reference to a "Eurocentric curriculum".

In this light, the editorial board of Koers extends an invitation to academics to study these recent developments from the vantage point of their respective disciplines in an academic context. We shall gladly publish articles from different fields that provide academic contextualisation and insight into this unprecedented action within a democratic society. Articles highlighting especially the issues related to decolonising, as well as a Eurocentric curriculum will be considered.

As a stimulant for such an issue of Koers, it is considered apposite to publish an opinion piece by John Kane Berman. It is a speech that he made in November 2015 at a meeting in Stellenbosch of academics from Afrikaans universities concerned about the direction that was being taken in the debate about Afrikaans as a language of instruction at universities. The essay is far more encompassing, though, and provides a platform for a discussion of the "decolonizing" of South African universities in the context of the recent events at universities. 


\section{UNIVERSITIES UNDER SIEGE}

Speech by John Kane-Berman of the South African Institute mni Association: Stellenbosch: 27th November 2015

When I was a student at Wits, one of the people who had a great influence on me was not among my formal teachers. His name was Robert Birley and he had taken early retirement from the was headmast one of the most fam High in Soweto. Its headmaster, Wilkie Kambule, was as distinguished among South African educationists as Birley was distinguished among South African educationists as Birley was among British. Birley also helped to found a library at Orlando High, which Kambule then named after him, to the annoyance
of the government. Seldom without a twinkle in his eye, Birley was the kind of man who would probably have enjoyed being was the kind of man who would probably have enjoyed being
arrested in Soweto, because the British press would then arrested in Soweto, because the British press would then arrested for teaching in Soweto".

Before he came to South Africa, Robert Birley's main claim to fame was his work in Berlin before he went to Eton. As the Second World War ended in 1945, he was appointed educational adviser to the military authorities in the British sector of Berlin, surrounded as it then was by the Soviet army in East Germany. His job was to denazify German education. One of his favourite quotations in many lectures that he gave around South Africa was from Julius Ebbinghaus, one-time rector of Marburg University, one of those which Hitler closed.

One fact remains, unfortunately, all too true. The German universities failed, while there was still time, to oppose publicly with all their powers the destruction of learning and of the democratic state. They failed to keep the beacon of freedom and right burning through the night of tyranny so that it could be seen by the entire world.

Birley came to Wits to support our efforts to keep that beacon alight as the German universities had failed to do. The main issue was the then government's legislation imposing apartheid on all universities. In our home-grown struggle as students and staff to defend our universities against the infamous Extension of University Education Act of 1959 we had the support not only of people such as Birley, but also of other distinguished academics from around the world. One was a former head of a Cambilige college, who entiled his Onecture a for siege". Another visitor was Senator Robert Kennedy, brother of the assassinated president, who spoke at the Simonsberg residence of this university in June 1966

So threats to academic freedom in South Africa are not new. But they are probably more extensive now. In my student days the key issue was the exclusion of black students from the "open" universities. A number of student leaders were banned, exiled, or detained without trial. None of this stopped us from speaking our minds and denouncing the works of the National Party as vociferously as we wished. And of course organisations such as the South African Institute of Race Relations, the Progressive
Party, and sections of the Press waged a non-stop campaign against the apartheid system. Despite various curbs on the apartheid that wo not exposed to the puble fow

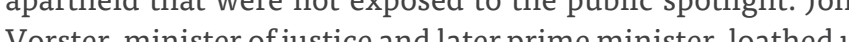
and threatened us, but he could not stop us.

The system we faced was authoritarian. For black students, it was much worse. Today's South African universities fac something more complex than apartheid authoritarianism. Freedom of opinion and expression are guaranteed by the Constitution as is academic freedom. We had only the commen law to rely on, and that was often overridden by legislation. But this didn't thop us making full use of our freedoms. Todan. But South Africans in business, the media, and academia practise a considerable degree of self-censorship. Political correctness rules the roost. At the same time, despite the fact that they now possess full democratic rights, students (as well as strikin workers and others) routinely use violence as a weapon have been doing so for most of the post-apartheid era. Most of the time they get away with it.

The condoning of violent student behaviour predates the advent of democracy. The most notorious case was in 1986 when students at UCT broke up meetings addressed by the Irish politician Conor Cruise O'Brien. Both UCT and Wits the persuaded him to cancel his lectures. But the worst of it was that a committee of enquiry at UCT exonerated the student and blamed him for provoking them - a classic case of blamin the victim. That two judges and a former vice chancellor condoned this assault on free speech makes it more shocking. But the impunity surrounding some of the mob rule on various campuses this year has the O'Brien affair among its precedents. Our universities face threats from within as well as from without. When I read media comments that support studen demands but fail to condemn their violent behaviour. I fear that the middle classes have taken leave of their senses.

Freedom of speech is the most obvious component of academic freedom. It implies freedom from intimidation and coercio on the campus from whatever quarter, as well as freedom from interference by the state. The essence of a university is that its members are able to seek the truth, to engage in battles of ideas, to argue to their hearts' content. That they are able to do so in an institution which in South Africa is heavily funded by taxpayers is an enormous privilege. But it is an essential one. Enlightened governments and enlightened donors will acknowledge this. freedom, without recognition that knowledge advances by tria and error, without willingness to shelter heretics, a university cannot do its job.

Part of that job is to challenge conventional wisdoms, no matter how widely they may be held or how much support they migh have among the powerful. And it goes without saying that students and teachers in freeuniversiteswillinevitably subject government and its policies to penetrating scrutiny. That too part of their job.

In my day academic freedom was usually defined as having four components: the freedom of the university to choose what o teach, how it should be taught, who should do the teaching, and whom should be taught. Racial restrictions on student admissions and on staff appointments were of course the most place at UCT in 1968 when the university council capitulated place at UCT in 1968 when the univesty council capitulated social anthropologist, Archie Mafeje, to a teaching post.

My SRC at Wits organised mass meetings, and large but disciplined street demonstrations, against this, resulting in my being informed by Prime Minister Vorster in his office in the Union Buildings that what we were doing would not be tolerated. When we asked him to clarify what would not be tolerated, he refused to do so, merely repeating his throet be and over again. Whether or not he genuinely believed his insinuations that we were busy stoking up the kind of student insinuations that we were busy stoking up the kind of student his threats and repressive measures, opposition intensified.

The violation of academic freedom that bothered us most racial prohibitions - has long gone. But in its place has come the ideology of demographic proportionality, or representivity as it is sometimes called, and the wider concept of transformation. Though often depicted as simply redress for the injustices of the past, these are part of a more comprehensive agenda, which is to bring about a National Democratic Revolution (NDR) in South Africa. The term "transformation" may seem vague or innocuous, but it is usually shorthand for the NDR.

The media generally pooh-pooh this revolutionary agenda, even though plenty of legislation to give effect to it has been enacted and even though the NDR is regularly reaffirmed at conferences of the African National Congress (ANC).

It has several components. The first is radical redistribution of wealth,income, and land. The second isto impose demographic proportionality on as many institutions as possible and so ensure that their staff complements are dominated by the African component of the black population. The third is to deploy loyal party cadres or apparatchiks to capture control of as many institutions as possible. And the fourth is to win the "battle of ideas" against ultra-leftism on the Left and "neoliberalism" on the Right.

The NDR is a blueprint for racial nationalism and partypolitical control. It involves more and more intervention in the economy, the expropriation of private property, the replacement of independent regulatory bodies with statutory ones, and diminishing tolerance of pivate institutions and private space. It is a wider threat to academic freedom, and to freedom in general, than was the previous government's interference with universities

Political developments seldom move in a straight line, and NDR thinking recognises the need for firmness in principle and dexterity in practice. The ANC is subject to all sorts of different pressures, and immediate implementation of the NDR would cause a night of capital, as well as other problems. So implementation has to be a matter of strategy and tactics.
Compromise is permissible as long as you do not lose sight of the ultimate objective. But step-by-step implementation would be precisy becase the threat is less obvious and likely to provoke resistance.

Although President Jacob Zuma said about six weeks ago that the ANC and the South African Communist Party (SACP) were moving in the same direction towards a "socialist revolution" and a "communist society", it's not clear how far the NDR will be pursued or how united the ANC is behind it.

But of one thing I'm sure. This is no time for further appeasement. One of the factors working to the advantage of
the NDR agenda is the tendency of institutions reluctantly to accept the supposed need for a particular policy, and then to try to tweak it a bit. The retired CEO of a major mining company told me a few months ago that he and some of his colleagues had wanted to oppose ideological interventions in the mining industry right from the start, but that they were outvoted by other mining houses. He says this was a mistake and that the intrusive legislation should have been fought in principle from the word "go".

The Institute did this with proposals in 1995 that would have given the government control of all non-governmental organisations by empowering one or another minister to replace all their boards with his own nominees. We mobilised a campaign against this and defeated it. However, similar proposals are mooted from time to time so constant vigilance is required.

Governments often get their way with bullying, obviating the need for legislation. One of the reasons South Africa has a free press today is that the newspaper industry has by and large resisted the bullying of the present goven ment as muc as it did that of the previous one. One editor - Joel Mervis of the Sunday Times - once said that freedom of the press was not a privilege for journalists but the right of the people to be informed. The same is true of academic freedom. It belongs to society, not to academics. When universities opt for silence or acquiescence, they do no service to their society. It is their duty to defend themselves.

The exploitation of history helps to foster the transformation Kruger, and others has boaden into wider denands. Universities are being told to "de-colonise" their curricula. The requirements. These egregious demands ignore the difficulty of retaining staff against the lure of companies in the private sector anxious to comply with racial quotas. They also ignore and appointment despite the dire consequences apparent throughout the public sector.

An American concept of "whiteness" is being used to tar whit people with collective guilt and so cow them into silence. Legitimate arguments for the retention of Afrikaans as the
medium of instruction at Stellenbosch are drowned out by 
references to the past. Given that past, you will not have an easy job countering the accusations being flung your way. And while Afrikaans at Stellenbosch may be the immediate target, the threat to academic freedom is wider and demands a wider response.

Moreover, those who assume that the attack on Afrikaners will not be followed by attacks on other minorities had better wake up. The coloured minority is already the victim of various forms of attack. Apartheid was a system of minority tyranny over a majority. Many people would rejoice if the boot were now to be put upon the other foot. But two wrongs don't make a right. Nor is it just to visit the sins of the fathers upon their children. At the same time, we should also remember that whatever attacks may be made on minorities, the major victims of South Africa's economically destructive policies and dysfunctional state are the poor, the jobless, and those without decent schools - for whom the ruling elite shows little concern.

Several recent books paint a bleak future. Even before the transition in 1994, people asked me whether we would go the way of Zimbabwe. My answer took the form of two questions, "Well, do you want us to? And if not, are you doing anything about it?"

We have the freedom to defend academic and other freedoms, including vital economic freedoms. We also have the freedom, and the intellectual capacity, to propagate ideas fundamentally different from those currently dominant. We need more academics, more journalists, more businessmen, more politicians, more unionists, and more institutions in civil society to join this battle. It is an opportunity to be grasped with both hands.

I will end with a quote from Goethe that was used by Bobby Kennedy when he spoke here all those many years ago: "He only earns his freedom and existence who daily conquers them anew." *

Annette Combrink Editor-in-Chief, Koers 